\title{
A comparison of resilience and mental health in parent of people with and without mobility impairment
}

\author{
Amene Mahmoodpour ${ }^{1}$, Setare Shojaee ${ }^{2}$, Diba Seif ${ }^{3}$ \\ 1-M.A. Psychology and Special Education, Department of Special Education, Shiraz University, Shiraz, Iran. \\ 2- Associate Prof, Department of Special Education, Shiraz University, Shiraz, Iran (Corresponding Author). \\ E-mail: bahareman@shirazu.ac.ir \\ 3- Associate Prof, Department of Special Education, Shiraz University, Shiraz, Iran.
}

Received: 02/04/2020

Accepted: 27/05/2020

\begin{abstract}
Introduction: Since disability and its associated problems are permanent, it can have a profound effect on the mental health and resilience of parents.

Aim: The aime of the present study was to compare the resilience and mental health in parents of people with and without mobility impairment.

Method: The statistical population of this causal-comparative research included all parents of people with and without mobility impairment in Shiraz city, whose children have 10-18years. The sample were 120 parents of children with mobility impairment was recruited by purposeful sampling and 120 parents of children without mobility impairment were selected through a multistage random sampling method from Shiraz city schools. The Connor-Davidson Resilience Scale (CD-RTS9) and mental health scale (GHQ28) was utilized for Collecting data. Data were analyzed by using Two-way ANOVA and MANOVA.
\end{abstract}

Results: Analysis of the findings showed resilience and mental health (physical symptoms, depressive symptoms, social functioning and anxiety) of parents of people with mobility impairment were significantly lower than parents of people without mobility impairment $(\mathrm{P}<0.001)$.

Conclusion: According to this finding it is suggested to design and implement appropriate intervention programs in order to improve mental health and resilienc in parents of children with mobility impairment.

Keywords: Resilience, Mental health, Parents, People with mobility impairment

How to cite this article : Mahmoodpour A, Shojaee S, Seif D. A comparison of resilience and mental health in parent of people with and without mobility impairment. Shenakht Journal of Psychology and Psychiatry. 2020; 7 (3): 1-15 .URL: http://shenakht.muk.ac.ir/article-1-626-en.pdf

Copyright $\odot 2018$ the Author (s). Published by Kurdistan University of Medical Sciences. This is an open access article distributed under the terms of the Creative Commons Attribution-Non Commercial License 4.0 (CCBY-NC), where it is permissible to download, share, remix, transform, and buildup the work provided it is properly cited. The work cannot be used commercially without permission from the journal. 


\title{
مقايسه تابآورى و سلامت روانى در والدين افراد با و بدون آسيب جسمى حركتى
}

\author{
آمنه محموديور '، ستاره شجاعى'، ديبا سيف \\ ا. كارشناسى ارشد روانشناسى و آموزش كود كان استثنايى، گروه آموزش كود كان استنايى، دانشكاه شيراز، شيراز، ايران.

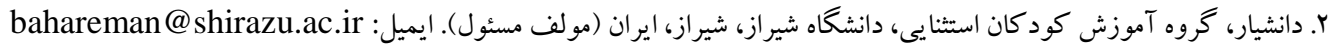

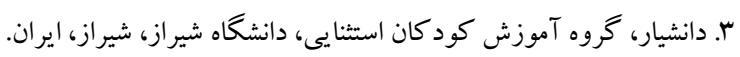

مقدمه: از آن جايى كه معلوليت و مشكلات مربوط به آن دائمى است، مىتواند روى سلامت روانى و تاب آورى والدين تأثير عميقى داشته باشد. هدف: هدف ثيزوهش حاضر مقايسه تابآورى و سلامت روانى در والدين افراد با و بدون آسيب جسمى حر كتى بود. روش: جامعه آمارى بزوهش على مقايسهاى حاضر، همه والدين افراد با و بدون آسيب جسمىحر كتى ساكن شهر شيراز بود؛ كه

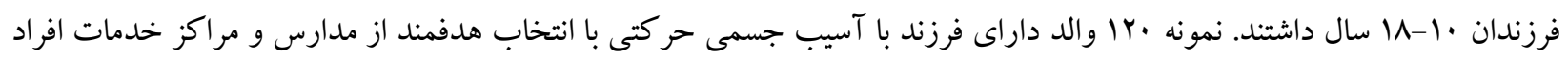

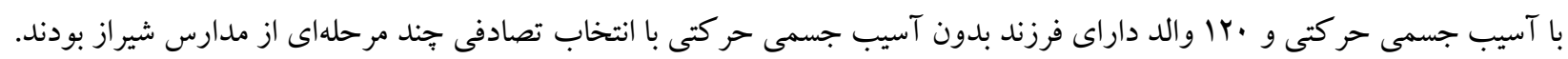

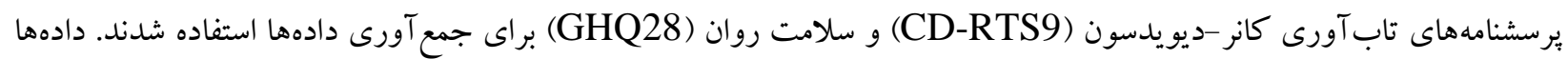

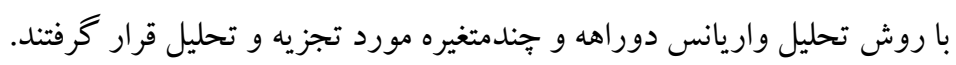
يافتهها: تحليل يافتها نشان داد تابآورى و سلامت روانى( علايم جسمانى، علايم افسردگى، كاركرد اجتماعى و اضطراب) والدين

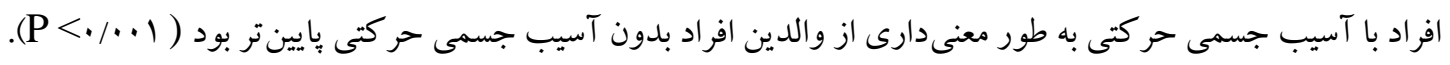
نتيجه كيرى: براساس يافتها بيشنهاد مىشود براى ارتقا سطح سلامت روان و تابآورى والدين افراد با آسيب جسمى حركتى،

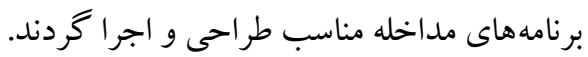
كليدوازهها: تاب آورى، سلامت روانى، والدين، افراد با آسيب جسمى حر كتى 
رو بررسى دقيقتر انواع فشارهاى روانى مىتواند از

مقدمه

اهميت بالايى برخوردار باشد.

ها درصد جمعيت جهان را افراد با انواع ناتوانى تشكيل

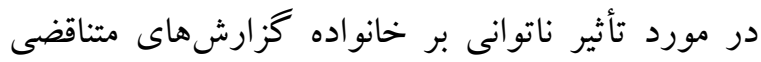

وجود دارد. به طورى كه برخى از تحقيقات به تأثير منفى مونى

كودكك با كمتوانى در خانواده و تفاوت عملكرد اين

خانوادهها با خانو ادههاى داراى فرزندان بدون كمتوانى

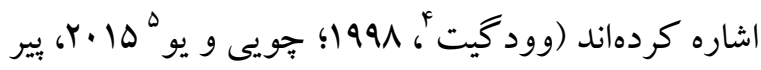

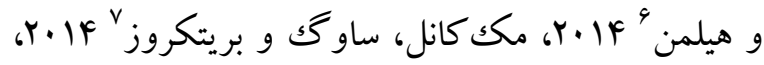

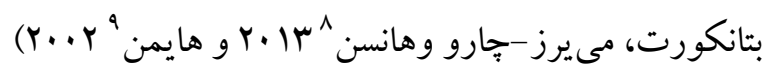
و برخى تحقيقات هم نشان دادهاند كه وجود فرزند با كمتوانى در خانواده مىتواند تأثير مثتى بر عملكرد خانواده داشته باشد و تفاوت معنادارى بين سطح عملكرد و فشار روانى خانوادههاى فرزندان با كمتوانى با لـ خانوادههاى فرزندان بدون ناتوانى مشاهده نشده است (رودرو بو كرتس "، 1999). با توجه به اين گزارشهاى متناقض كه آن هم به شكل

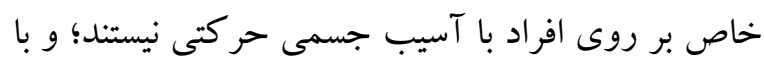
توجه با اين كه آسيبهاى جسمى حركتى و رفتارهاى ناشى از آن امرى ثابت و يايدار است، يُزوهش بر روى

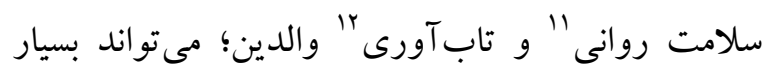

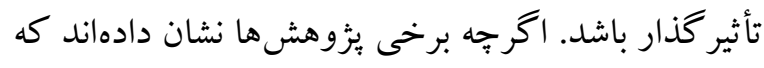
خانوادههايى كه داراى فرزند با انواع بيمارى يا كمتوانى هستند؛ سطوح بايين ترى از تاب آورى را تجربه مى كنند و در بيشتر مواقع سلامت روانى آنها به خطر مىافتد

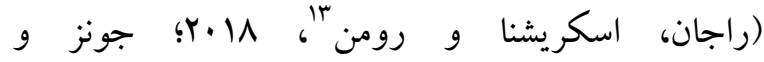

4- Woodgate

5 - Choi \& Yoo

${ }^{6}$ - Peer \& Hillman

7- McConnell, D., Savage, A., \& Breitkreuz

8 - Betancourt, Meyers, Charrow \& Hansen

9 - Heiman

${ }^{10}$ - Roder\& Boekaerts

${ }^{11}$ - Mental health

${ }^{12}$ - Resilienc

${ }^{13}$ - Rajan, Srikrishna \& Romate مىدهند؛ و احتمال كمتوانى براى تمام افراد جامعه بر اثر حوادث غيرمترقبه و افزايش سن و گسترش بيمارىهاى مزمن هر ساله در حال افزايش است؛ كه در اين ميان در برخى از كشورها، بيشترين آمار به آسيبهاى جسمى حركتى مربوط مىشود؛ به گونهاى كه بزر كترين اقليت غير نزادى در جهان را تشكيل مىدهند (سازمان بهداشت

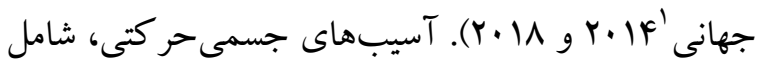
آسيبهايى است كه به علت نابهنجارى مادرزادى (براى مثال كجى و كوتاهى با، فقدان برخى از اعضاى بدن و غيره)، بيمارى (براى مثال فلج اطفال، سل و غيره) و علل ديخر (مثل فلج مغزى، قطع عضوى از بدن، شكستكى يا

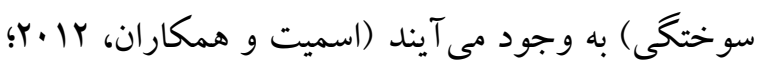
تر جمه همتى علمدارلو و همكاران، هوسبا ). آسيبهاى جسمى حركتى در صورت موقتى بودن مشكلات و محدوديتهاى بسيارى را براى فرد و

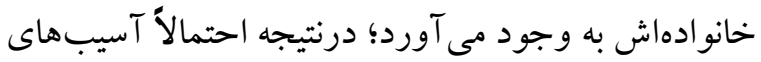
جسمى حركتى دائمى و مزمن؛ اثرات طولانى مدت عاطفى، اجتماعى و اقتصادى بر خانواده دارند. مراقبت دائم از كودكى داراى ناتوانى مستلزم شكيبايى زياد و فدا نمودن هدفهاى شخصى از جانب والدين است. روابط آشفته، تغيير در اهداف فعاليتهاى خانواده، افزايش فشارهاى اقتصادى، مشكلات جسمانى و تحصيلى و احساس كناه؛ از نخستين تجربههاى خانوادههاى داراى كودك با نياز ويزه است (لايت فوت، هيل و لاليبرت'، (Y.1). (Y. آنها فشار و تنشهاى بالاى روانى و سطح عملكرد خانوادگ

\footnotetext{
1. World Health Organization

2. Lightfoot, Hill, \& LaLiberte

3 - Dyson
} 
جامعه خود باشد (سازمان بهداشت جهانى، Y. Y T) نتايج بررسى متغيرهاى تابآورى و سلامت روانى در افراد با آسيب متفاوت بودهاند، مثل رابطه تابآورى و وركي حمايت اجتماعى متناسب با نياز در همسران افرادى كه

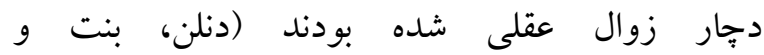

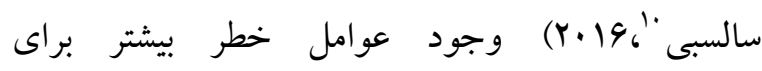
تابآورى در جوانانى كه از افراد كوجٍكتر در مراكز نخهدارى مراقبت مى كردند؛ در مقايسه با ساير جوانانى

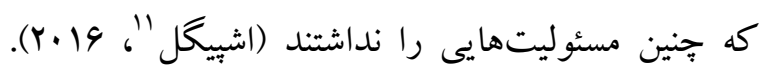
همجِنين پِيnن بودن تابَآورى و سلامت روانى در خانوادههايى كه يكى از اعضا دجار ناتوانى يا بيمارى است، نسبت به خانوادههايى كه جنين شرايطى را ندارند،

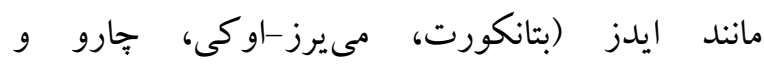

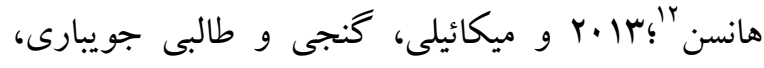
اجوب()، خانوادههايى كه از افراد با انواع بيمارىهاى روانى مراقبت مى كنند (بيشاب و كريف، ها ·r؛ لال و

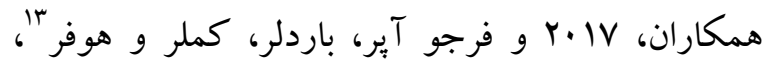
ها +r). داراى فرزند با سندرم داون (جويى و يو (ها. (Y) يا با مشكلات رفتارى و ناتوانى هاى ذهنى و يا اختلال هاى

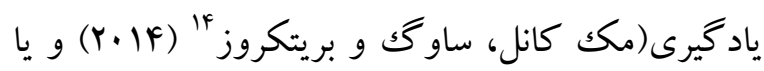

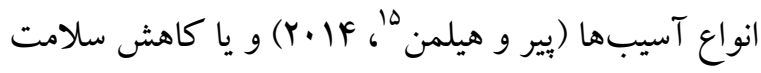
روان و بهزيستى روانشناختى در خود افراد با آسيب جسمى حر كتى (برارى و غفارى؛ (هوسا).

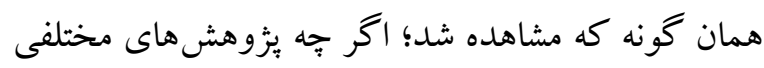
در حوزه افراد با نيازهاى ويزه يا خانوادهها و والدينشان

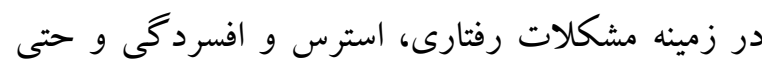

\footnotetext{
${ }^{10}$ - Donnellan, Bennett \& Soulsby

11. Shpiegel

12 - Betancourt, Meyers- Ohki, Charrow, \& Hansen

${ }^{13}$ - Frajo-Apor, Pardeller, Kemmler, \& Hofer

${ }^{14}$ - McConnell, Savage, \& Breitkreuz

15 - Peer \& Hillman
}

همكاران'

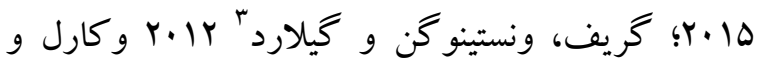

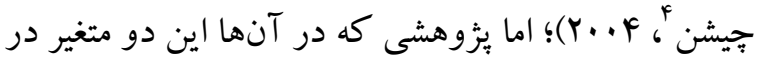
در والدين افراد با آسيب جسمى حركتى بررسى شده باشد؛ مشاهده نشد. بايد به اين نكته اشاره كرد كه تابآورى كيفيتهاى فردى است كه براى ساز گارى

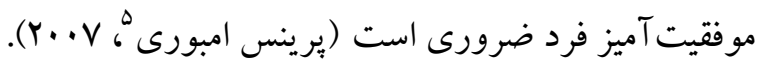

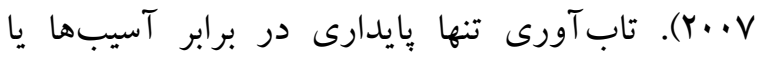
شرايط تهديد كننده و يا حالت انفعالى در رويارويى با شرايط خطرناكك نيست، بلكه شركت سازنده و فعال در محيط بيرامون خود است. مىتوان كفت تاب آورى توانمندى فرد در برقرارى تعادل زيستى- روانى، در

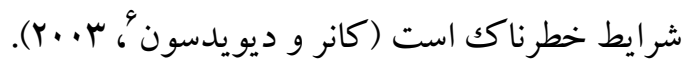
با توجه به اين كه همواره بين تاب آورى و سلامت روانى در بيشينه يُزوهشى ارتباط مشاهده شده است (لال و

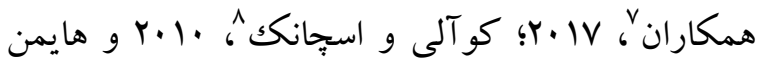

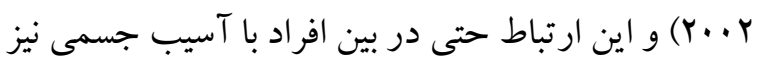

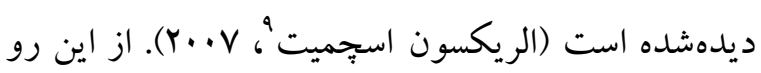
بررسى سلامت روانى والدين افراد با آسيب جسمى حركتى در مقايسه با والدين داراى فرزندان بدون آسيب جسمى حركتى نيز مى تواند به عنوان يكى از متغيرهاى مورد مطالعه باشد. سلامت روانى حالتى از بهزيستى روانى

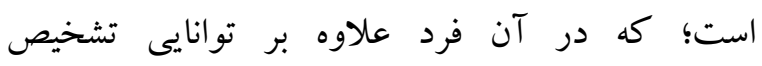
توانيىهاى بالقوه خود، قادر است با استرسهاى روزمره مقابله نمايد و در عين حال يكك فرد كار آمد و مؤثر براى

\footnotetext{
1 - Jonse

2- Bishop \& Greef

3 - Greeff, Vansteenwegen \& Gillard

4- Carle \& Chassin

5 - Prince-Embury

6- Conner \& Davidson

7. Lal \& et. al

8- Quale \& Schanke

${ }^{9}$ - Alriksson-Schmidt
} 
جسمى حر كتى به شيوه هدفمند بود. بدين صورت كه بعد

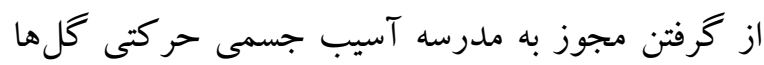
( كه تنها مدرسه ويزه افراد با آسيب جسمى حر كتى شيراز است) و مراكز تلفيقى و كلينيكهاى توانبخشى كه در آنها افراد با آسيب جسمى حركتى مشغول به تحصيل يا دريافت درمان، بودند؛ مراجعه شد و همه افراد با آسيب جسمى حركتى 11- •|1 سال كه در عين حال دجار ساير كمتوانىها، مثل كم توانى ذهنى يا بيمارى جسمى، نبودند و تحت سريرستى بدر و مادر خود بودند، به عنوان نمونه انتخاب شدند تا برسشنامهها براى تكميل به والدين 4. آنها داده شود؛ كه تعداد آنها شامل •rا نفر فرزند دختر و •9 يسر) و بالطبع ·r| والد بود. در مرحله بعد براى جمع آورى دادهها از والدين افراد بدون آسيب

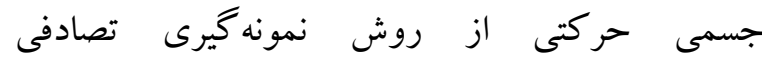
جندمرحلهاى استفاده شد. بدينصورت كه فهرستى از مدارس متوسطه اول و دوم جهار ناحيه شهر شيراز تهيه شد و به صورت تصادفى جهار دبيرستان دخترانه و جهار دبيرستان يسر انه انتخاب شدند و با مراجعه به دبير ستانهاى ياد شده براى همتا كردن افراد گرووه بدون آسيب با كروه آسيب جسمى حركتى از لحاظ سن (11-.1 ساله) و جنسيت، تعداد •با نفر فرزند (·4 دختر و •9 بسر) انتخاب شدند و بالطبع از •rا والد خواسته شد در يُّوهش شركت نمايند. معيارهاى ورود سن فرزند، داشتن آسيب جسمى حركتى و معيارهاى خروج شامل نداشتن عقبماندگى ذهنى يا ساير بيمارىهاى خاص بود. برسشنامه تاب آورى و سلامت روانى توسط والدين تكميل شد. شايان ذكر است كه جمع آورى تعدادى از يرسشنامها كه در مرحله اول ناقص پِرشده بودند؛ با

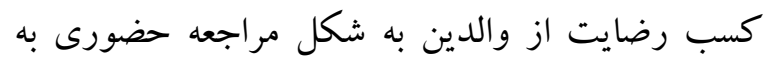

سلامت روان انجام شده، ليكن يزوهشى كه تاب آورى و سلامت روانى والدين افراد با آسيب جسمى حركتى را لروال با والدين افراد عادى باهم مقايسه كند مشاهده نشد. در عين حال با توجه به اينكه بر اساس بيشينه، جنسيت نيز

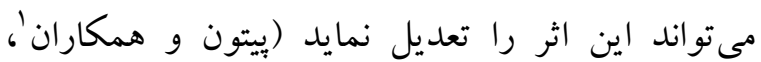
1 1.ب! ملكشاهى و فلاحى، هوبا و آرمان و فيروز كوهى مقدم،rar|)؛ به همين دليل، ئزوهش حاضر به دنبال

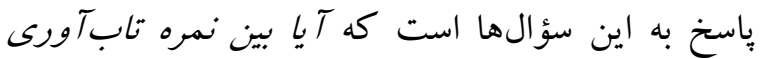
والدين افراد با و بلدون آسيب جسمى حركتى بر حسب ليب جنسيت فرزند تغاوت معنىدارى وجود دارد؟ و آيا بين نمره كل سلامت روانى و خرده مقياسهاى آن (شامل نشانهایى جسمانى'، اضطراب'، كاركرد اجتماعى'، علائم افسردكى) در والدين افراد با و بلون آسيب جسمى حركتى بر حسب جنسيت فرزند تناوت معنىدارى وجود دارد؟ جرا كه مشخص شدن پاسخ اين سؤالهاى بيزوهشى مى تواند راهگشاى متخصصان و و كارشناسان حوزه سلامت روان و افراد با نياز ويزه در جهت طراحى و اجراى برنامههاى مداخلهاى مناسب و درخواست هزينهاى مورد نياز براى حمايت اجتماعى از اين والدين كردد.

روش يثزوهش حاضر از نوع على مقايسهاى است كه در آن والدين افراد با و بدون آسيب جسمى حركتى مورد مقايسه قرار گرفتند. جامعه شامل همه والدين افراد با و برون بدون آسيب جسمى حركتى ساكن در شهر شيراز بود. روش نمونه گيرى براى انتخاب والدين افراد با آسيب

\footnotetext{
1- Patton, McPherson, Emerson \& Lennox

2 - Physical symptoms

3 - Anxiety

${ }^{4}$ - Social work
} 
روانى نيست، بلكه منظور آن ايجاد تمايز بين سلامتى و

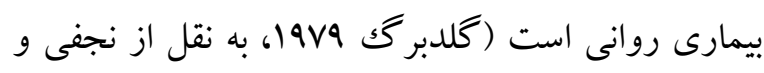

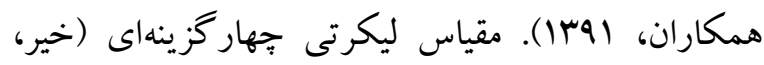
كمى، زياد و خيلى زيـاد) · تا ب است. دو شـيوه نمره

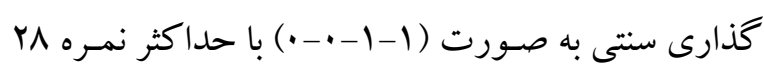

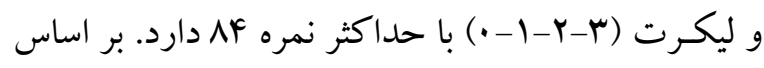
يخوهشهاى متعدد بهترين نقطه برش براى تمييز

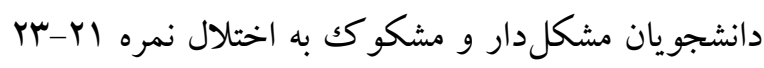
است (مهدوى و همكاران، الوسا). اين برسشنامه داراى جهار خرده آزمون است كه عبارتاند از: نشانهاى جسمانى(سؤالهاى I-1) براى بررسى وضعيت سلامت عمومى و علائم جسمانى در يكك ماه كذشته، اضطراب (سؤالهاى N-1F) براى بررسى علائم و نشانهاى بالينى اضطراب شديد، بى خوابى، تحت فشار بودن، عصبانيت و دلشوره، كاركرد اجتماعى (سؤالهاى ها-1(Y)، براى بررسى توانايى فرد در انجام كارهاى روزمره، احساس رضايت در انجام وظايف، احساس مفيد بودن، قدرت يادگيرى و لذت بردن از فعاليتهاى روزمره زندگى و و

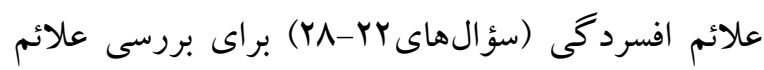
اختصاصى افسردگى از قبيل احساس بى ارزشى، ناميدى،

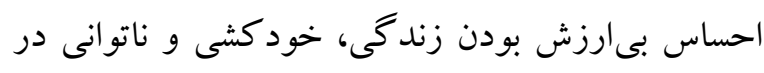

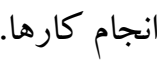

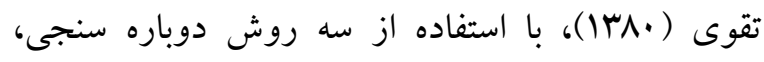
تصنيفى و ثبات درونى؛ ضريب بايايى براى كل مقياس را

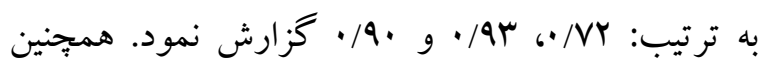
روايى بر اساس سه روش روايى همزمان، تحليل عاملى و

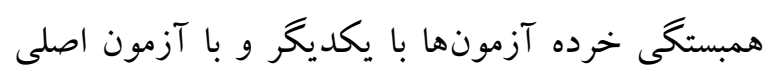
استفاده كرد كه نتايج نشان دهنده روايى قابل قبول اين مقياس است. در مجموع تحقيقات زيادى كه در خصوص
منزل مجدداً تكميل و جمع آورى گرديد. جهت تجزيه و تحليل دادهها در سطح آمار استنباطى از تحليل واريانس دوراهه و تحليل واريانس جندمتغيره استفاده شد.

ابز ار مقياس تابآورى كانر و ديويدسون (CD-RTS9): اين مقياس توسط كانر و ديويدسون (CD-RTS9) (r... (Y)

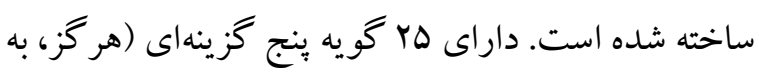
ندرت، كاهى اوقات، اغلب، هميشه) است. اين مقياس در ايران توسط محمدى (IMAF) هنجاريابى شده است. در حال حاضر فقط نمره كل تابآورى براى هدفهاى يثزوهشى معتبر است. حداقل نمره تاب آورى آزمودنى در اين مقياس صفر و حداكثر نمره صد است؛ يعنى نمره فرد در يكك مقياس ليكرتى بين صفر (كاملاً نادرست) تا جهار

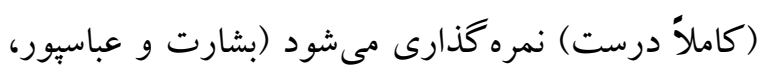

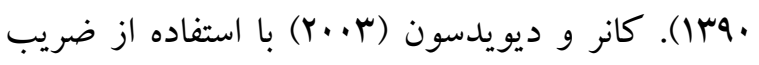

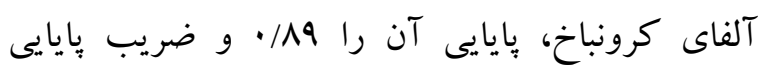
حاصل از روش باز آزمايى در فاصله جهار هفتهاى را نيز

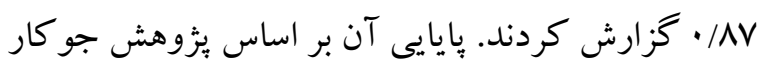

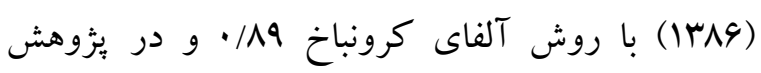

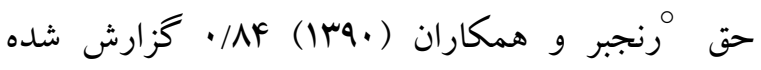
است. در بثزوهش حاضر بايايى مقياس تاب آورى هV/ • و روايى آن برابر · •/ • خزارش شد. مقياس سلامت روانى ' (28GHQ): مقياس سلامت روانى كلدبرك و هيلر (19V9) داراى Y Y سؤال و يكك ابزار غربالكرى خود گزارشى است كه در مجموعههاى بالينى با هدف رديابى كسانى كه دجار يكك اختلال روانى هستند مورد استفاده قرار مى گيرد. هدف اين يرسشنامه دستيابى به يكك تشخيص خاص در سلسله مراتب بيمارى

\footnotetext{
1. General Health Questionnaire-28 (GHQ-28)
} 


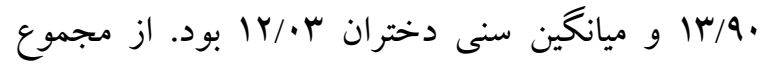

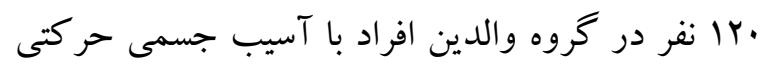
بيشترين فراوانى با تحصيلات كارشناسى ( •9 نفر) و در

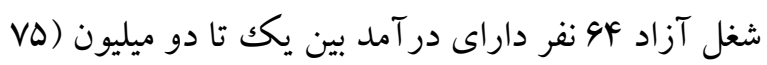
درصد) و از •rا نفر در گروه والدين افراد بدون آسيب جسمى حركتى بيشترين فراوانى با تحصيلات دييلم (ب)

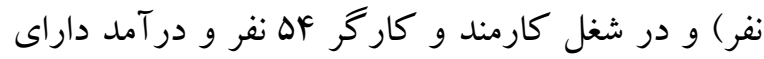

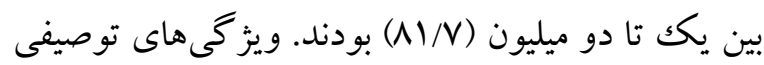

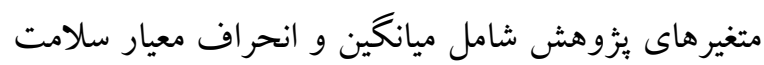
روانى و تاب آورى در دو گروه بر حسب جنسيت در جدول آ آورده شده است.
بررسى روايى و يايايى اين مقياس انجام شد، مشخص شد كه اين مقياس از روايى و بايايى مناسبى برخوردار است. در يُزوهش حاضر براى بايايى سلامت روانى ضريب

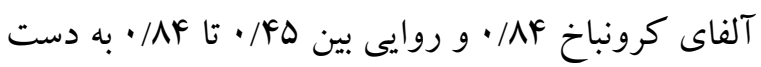

\section{يافتهها}

از كل افراد هر دو گروه والدين افراد با و بدون آسيب جسمى حركتى تعداد آزمودنى ها بر اساس جنسيت فرزند شامل •ه درصد يسر و •ه درصد دختر بودند كه در گروه والدين افراد با آسيب جسمى حر كتى ميانخين سنى بسران

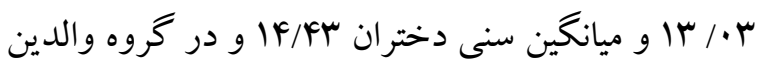
افراد بدون آسيب جسمى حركتى ميانگين سنى بسران

جدول ا ميانكين و انحراف معيار تابَآورى و سلامت روانى والدين افراد با و بدون آسيب جسمى حر كتى بر اساس جنسيت فرزند

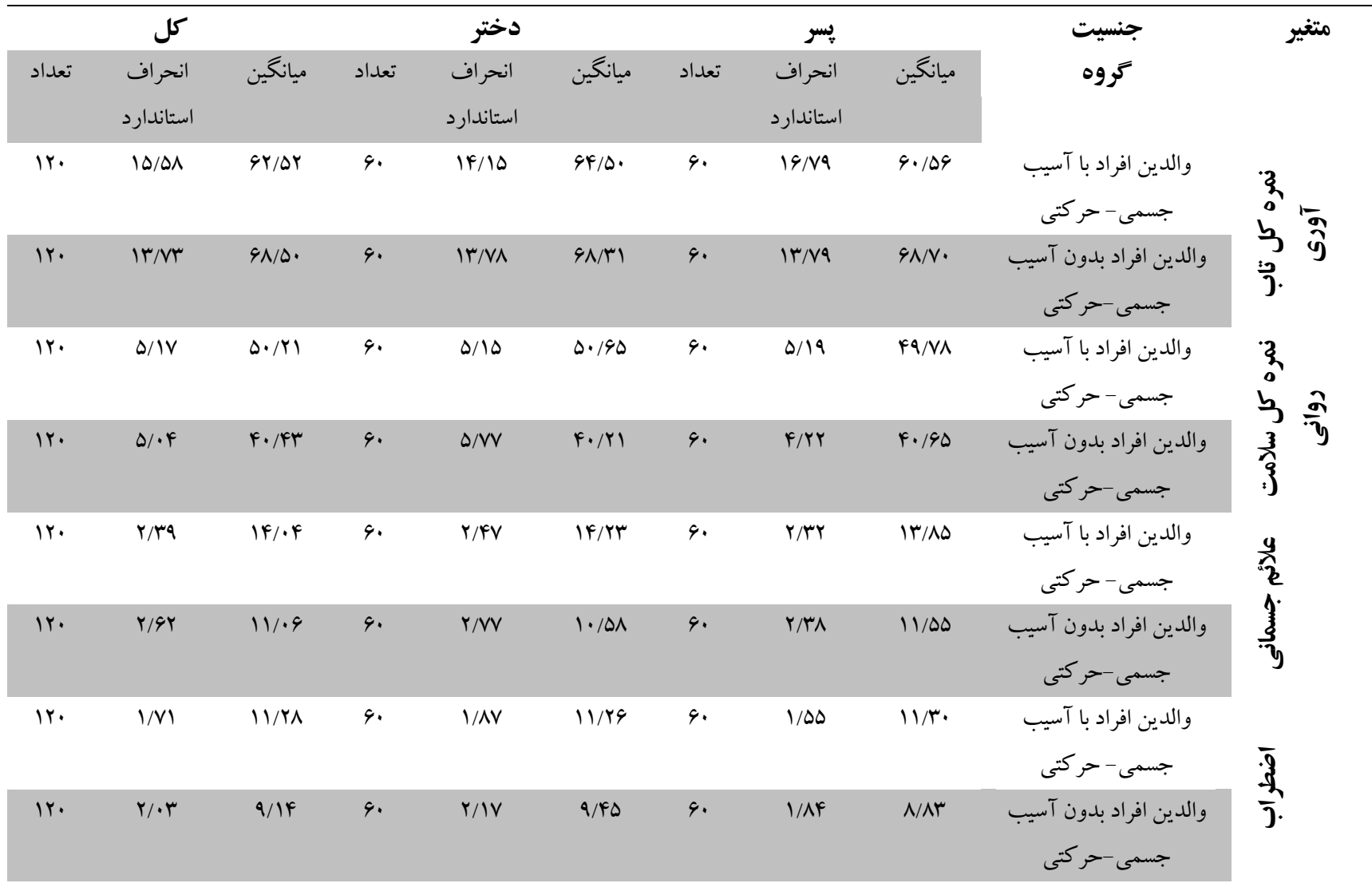




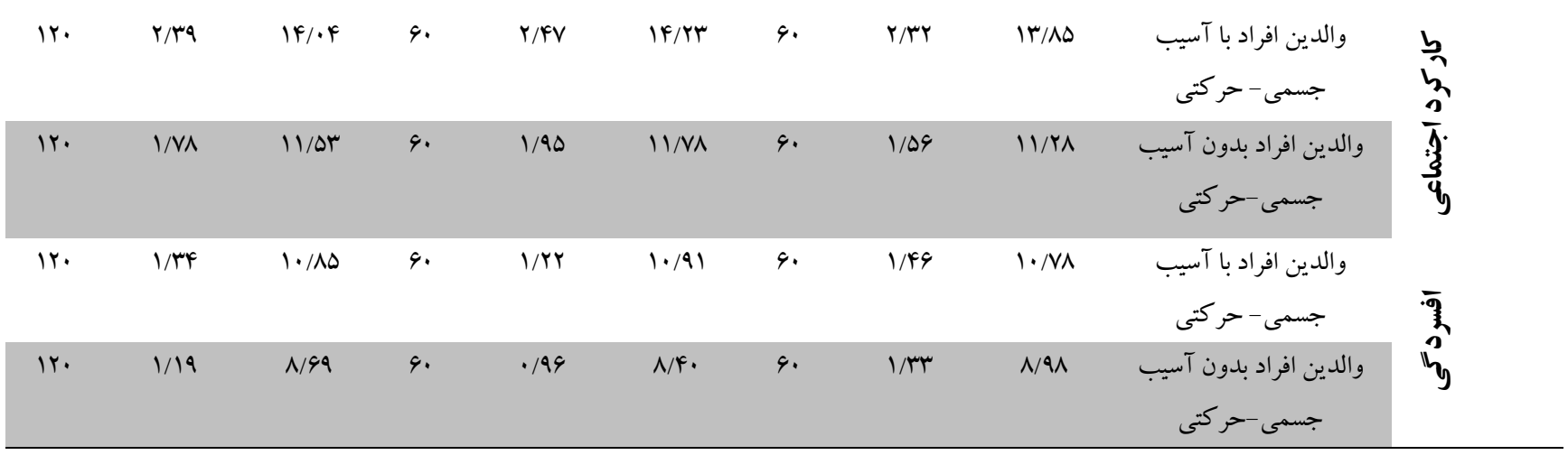

معنادارى تفاوت، استفاده شد.

بيش از انجام آزمونها مفروضههاى اصلى با استفاده از آزمون لوين به منظور بررسى همكنى واريانسها و همجنين آزمون كولموكروف اسميرنوف جهت بررسى نرمال بودن توزيع نمرات مورد بررسى قرار كرفت كه نتايج آنها در جدول Y مشاهده مى گردد.
همانطور كه در جدول ا مشاهده مىشود ميانخين نمره كل تابَآورى والدين افراد با آسيب جسمى حركتى نسبت به والدين افراد بدون آسيب جسمى حر كتى كمتر است. همجينين ميانكين خرده مقياسهاى سلامت روانى والدين افراد با آسيب جسمى حركتى نسبت به والدين افراد بدون آسيب جسمى حر كتى، بيشتر است. ازاينرو از تحليل واريانس دوراهه و جند راهه به منظور آزمون

جدول ب نتايج آزمون نرمال بودن توزيع و آزمون لوين

\begin{tabular}{|c|c|c|c|c|}
\hline \multicolumn{2}{|c|}{ كالمو كروف اسميرنف } & \multicolumn{2}{|c|}{ آزمون لوين } & \multirow{2}{*}{ مؤلفه ها } \\
\hline سطح معنادارى & آماره & سطح معنادارى & نسبت F & \\
\hline$\cdot / W F$ & .1991 &.$/ \mathrm{rV}$ & 1/19 & تاب آورى \\
\hline 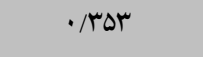 & . /94. &.$/ \mathrm{Fr}$ & l/Ar & سلامت روانى \\
\hline$\cdot / Y \Delta I$ & $.19 V \wedge$ & $\cdot 1 \cdot \mathrm{Va}$ & $r / Y q$ & خرده مقياس علائم جسمانى \\
\hline$\cdot / F \Delta 1$ & $\cdot / 941$ & $\cdot / \cdot v \Delta$ & T/M & اضطراب \\
\hline$\cdot / M F \mid$ &.$/ 941$ & .1 .90 & $r / \Delta V$ & كار كرد اجتماعى \\
\hline 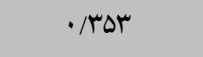 & . $/ 94$. &.$/ 1 r$. & $1 / \wedge 9$ & علائم افسردگى \\
\hline
\end{tabular}

واريانس ها براى همه متغيرها تائيد مى گردد و استفاده از از آنجايى كه مقدار p براى همه متغيرها معنادار نيست تحليل واريانس دوراهه و جند راهه امكانيذير است. (ه) • (p) بنابراين مفروضه نرمال بودن و همخنى

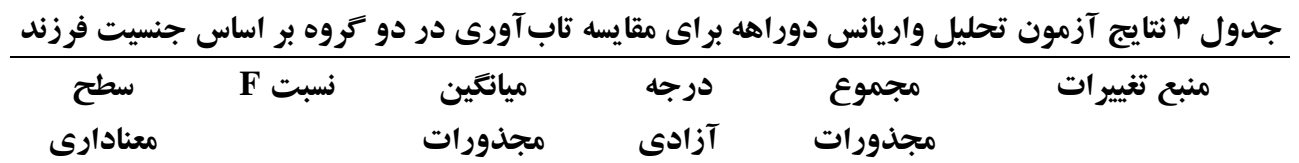


9 مقايسه تاب آورى و سلامت روانى در والدين افراد باو بدون آسيب جسمى حركتى

\begin{tabular}{|c|c|c|c|c|c|}
\hline.$/ \mu r$ & $9 / 94$ & $r \mid F r / \cdot r$ & 1 & YIFY/.r & كروه \\
\hline . & $\cdot / A \vee$ & $1 / 9 / \cdot r$ & 1 & $1 \wedge 9 / \cdot r$ & جنسيت \\
\hline \multirow[t]{3}{*}{. KOS } & $1 / 79$ & rVq/D. & 1 & rVq/D. & تعامل كروه و جنسيت \\
\hline & & $r \mid Q / 9 V$ & rrs & $\Delta \cdot \wedge 99 / \Gamma)$ & خطا \\
\hline & & & TF. & 1.ArArQ & مجموع \\
\hline
\end{tabular}

(F=•/AV بين گروهى نشان مىدهد كه اثر تعاملى گروه و جنسيت

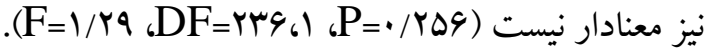

نتايج جدول ب نشانكر آن است كه متغير نمره كل

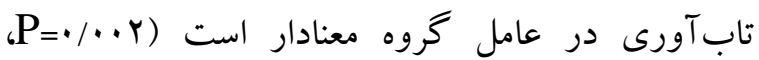

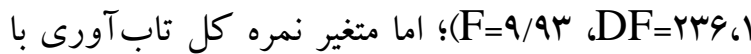

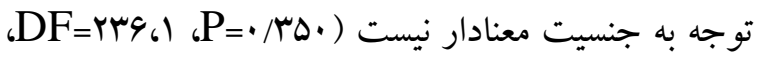

\begin{tabular}{|c|c|c|c|c|c|}
\hline معنادارى سطح & نسبت F & مجذورات مينين & آزادى درجه & مجذورات & منبع تغيرات \\
\hline.$/ \cdot \cdot 1$ & $r / 9 / I V$ & $\Delta V F Y / A I$ & 1 & $\Delta V F Y / A I$ & كروه \\
\hline - N VFr & .11 & $r / A)$ & 1 & Y/AI & جنسيت \\
\hline \multirow[t]{3}{*}{. RYG } &.$/ 94$ & ro/ro & 1 & $r \Delta / r \Delta$ & تعامل كروه و جنسيت \\
\hline & & re/r. & rrq & $9114 / 99$ & خطا \\
\hline & & & rF. & $\Delta \cdot \Delta \ldots$ & مجموع \\
\hline
\end{tabular}

نتايج جدول F نشانگر آن است كه متغير نمره كل سلامت

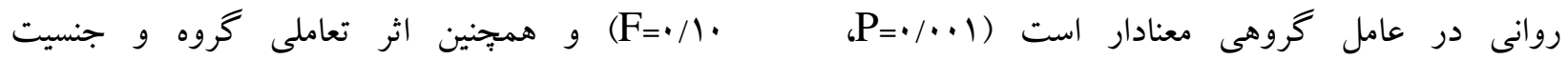

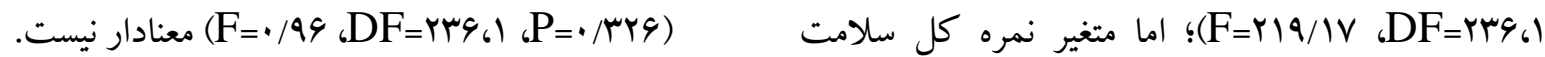

\begin{tabular}{|c|c|c|c|c|c|c|}
\hline اتا & معنى سطح & آزادى خطا & درجه آزادى & $\mathbf{F}$ & مقدار & لامبدا ويلكز منبع \\
\hline$\cdot / \Delta 9$ &.$/ .1$ & rTr & F & $V Q / 1 \Delta$ & $\cdot / \mu r$ & كروه \\
\hline.$/ . \Delta$ &.$/ 11 V$ & TrT & F & $1 / \cdot 1$ & $\cdot / 90$ & جنسيت \\
\hline$\cdot / \cdot \Lambda$ & .1 .91 & TrT & F & $r / .9$ & $\cdot / 9 r$ & تعامل كروه و \\
\hline
\end{tabular}

وابسته معنادار است. به همين دليل براى بررسى اينكه اين

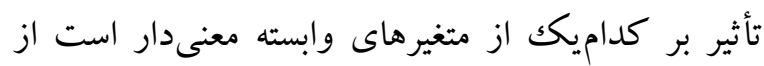
تحليل واريانس تجندمتغيره استفاده شده است كه نتايج آن
بر اساس دادههاى مشاهده شده در جدول ها اثر جنسيت و تعامل گروه و جنسيت بر تر كيب خطى متغيرهاى وابسته معنادار نيست؛ اما اثر گروه بر تركيب خطى متغيرهاى 


\section{جدول \& نتايج آزمون تحليل واريانس جندمتغيره براى هر يك از متغيرهاى وابسته}

\begin{tabular}{|c|c|c|c|c|c|c|}
\hline \multicolumn{2}{|c|}{ تعامل كروه و جنسيت } & \multicolumn{2}{|c|}{ جنسيت } & \multicolumn{2}{|c|}{ كروه } & منبع واريانس \\
\hline سطح معنى & $\mathrm{F}$ & سطح معنى & $\mathrm{F}$ & سطح & $\mathrm{F}$ & متغير \\
\hline 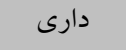 & & 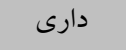 & & معنى دارى & & \\
\hline$\cdot 1.9 \mathrm{~V}$ & $r / \Gamma \Lambda$ & $\cdot / 499$ & $\cdot / \Lambda r$ & $\cdot \cdots 1$ & rQ/AD & علائم جسمانى \\
\hline$\cdot / \backslash \Lambda \mid$ & $1 / \wedge$. & - /rra & $1 / F \Delta$ &.$/ .1$ & $V \Lambda / Y q$ & اضطراب \\
\hline$\cdot \mid \Delta M^{\prime}$ &.$/ 4$ & .11 .9 & r/9Y & $\% \cdot \cdot 1$ & $\Lambda F / V \Lambda$ & كار كرد اجتماعى \\
\hline$\cdot / \mathrm{VA}$ & $1 / N$ &.$/ 191$ & $1 / 91$ &.$/ \cdot 1$ & $\mid v 9 / r$. & علائم افسردمى \\
\hline
\end{tabular}

اعضاى آن خانواده و يا فرزندشان دجار يكك نوع كمتوانى يا بيمارى خاصى است، سطح تابآورىشان نسبت به خانوادههاى افراد بدون آسيب در سطح پايين ترى قرار دارد. در تبيين يافته يزوهش حاضر مى توان كفت كه عدم دسترسى به امكانات آموزشى، وجود بيمارهاى روانى، بىثباتى خانوادهها و بزهكارى، مسائل اقتصادى و فقر در خانوادهها سطح تابآورى در افراد را

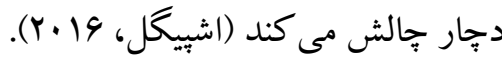
در مورد يّايين بودن سلامت روانى علىرغم عدم معنى

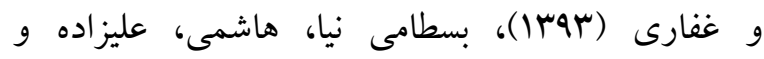
دستوريور (Y.19)، لال و همكاران (Y.IV)، رجبى و و (Y. (Y)

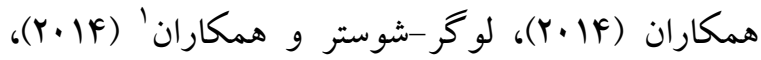

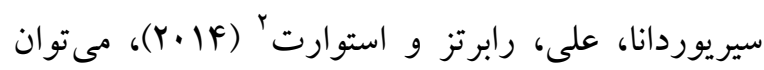
اشاره نمود كه نشان دادند جهطور وقتى مشكلات و و مسائل متعدد و بيمارىها و ديخر شرايط خاص و دشوار وارد زندگى افراد مىشود؛ مىتواند سطح سلامت روان رادر آنها به مخاطره بيندازد. در مورد يايين بودن نمره والدين افراد با آسيب جسمى

${ }^{1}$ - Lueger- Schuster\& et.al

${ }^{2}$ - Siriwardhana, Ali, Roberts \& Stewart
براساس جدول 4 تأثير گروه بر همه خرده مقياسهاى سلامت روانى؛ معنادار است. بدينصورت كه والدين افر اد با آسيب جسمى حر كتى نسبت به والدين افراد بدون آسيب جسمى حركتى نمرات بيشترى در خرده مقياسهاى سلامت روانى به دست آوردند؛ اما در هر يكك از خرده مقياسهاى سلامت روانى با توجه به جنسيت، اين اثر معنادار نبود. همجنين نتايج نشان مىدهد كه اثر تعاملى كروه و جنسيت نيز در هر يكك از خرده

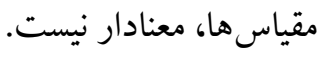
نتايج نشان داد تابآورى والدين افراد با آسيب جسمى حركتى از والدين افراد بدون آسيب جسمى حركتى پايينتر بود، ولى از نظر جنسيت تفاوتى وجود نداشت. همسو با نتيجه مذكور، در يثوهشهاى خدابخشى،

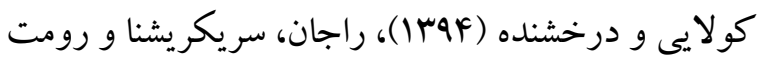
و جو و يو (Y) (Y)

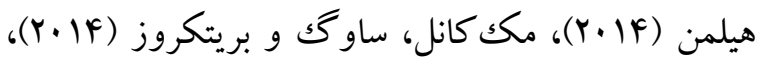

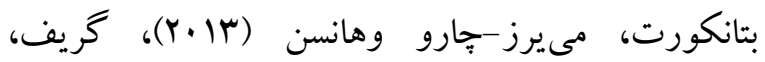

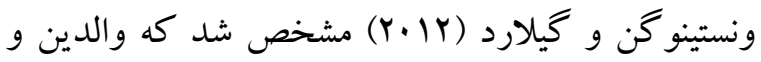
خانو ادههايى كه به نحوى دجار جالش شدهاند و يكى از 
آرزو داشتند يسرانشان در آينده زندگى مستقل و شغلى

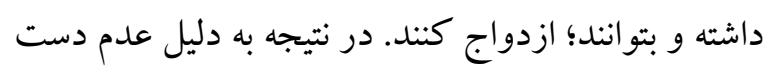
يافتن به اين خواستهها، فشار روانى و عاطفى در آنان

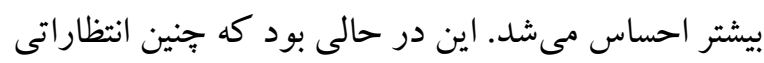

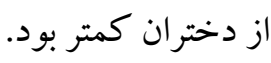

\section{نتيجه كيرى}

در تبيين يايين بودن تاب آورى و سلامت روانى والدين

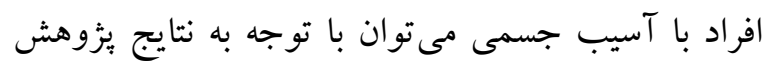

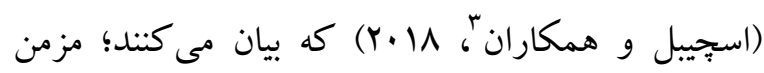
بودن شرايط جسمى اين كودكان، زمانهاى طولانى و مداوم مراقبت از اين كود كان، نيازها و فشارهاى اقتصادى بسيارى براى كل اعضاى خانوادههاى آنان به وجود مى آورد. احتمال دارد بتوان وجود تفاوت معنادار بين دو بكواي كروه والدين در يثزوهش حاضر را به عواملى مانند فقر اقتصادى-فرهنگى، وجود مشكلات خانوادكى و عدم دسترسى به خدمات آموزشى و بهداشتى نسبت داد؛ به كونهى كه در مراجعهها به منازل براى دريافت برسشنامهها و كزارشهاى معلمان اين فقر اقتصادى و فرهنگى و آموزشى كاملاً مشهود بود. از طرف ديخر نداشتن اطلاعات و دانش كافى در مورد نحوه دريافت حمايت اجتماعى و عاطفى مشكلات آنها را مضاعف مىساخت. اين در حالى است كه يتون و همكاران (Y.|N) كولكارنى" (Y) (Y.Mو) عوامل بهزيستى روانى در مادران افراد با آسيبهاى ذهنى را حمايت اجتماعى، داشتن اطلاعات و آكاهى مورد نياز، امكانات آموزشى و و اقتصادى دانستند.

5 - Schaible \& et al

${ }^{2}$ - Resch \& et. al

${ }^{3}$ - Mohan \& Kulkarni
حركتى در خرده مقياسهاى سلامت روان مىتوان از

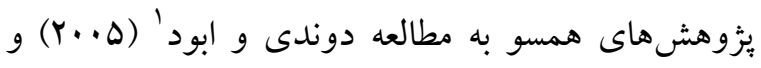

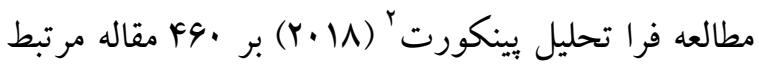
اشاره نمود كه نشان دادند نشانهاى افسردگى در والدين افر اد با آسيبهاى جسمى مزمن از جمله فلج مغزى نسبت به ساير ناتوانىها بيشتر است. يا بثروهش بتانكورت، مى يرز-اوكى، جارو و هانسن (r|r. (Y) كه با همسويى غيرمستقيم نشاندهنده بروز علائم جسمانى، اضطراب و و علائم افسردگى بالا و كاركرد اجتماعى پيايين در خانو ادههاى مبتلا به ايدز بود. در مورد عدم معنى دارى جنسيت بيزوهش آرمان و و

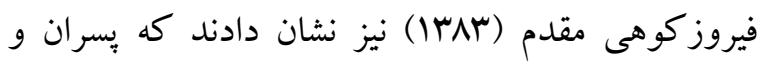
دختران كمتوانذهنى تأثير يكسانى بر والدين خود داشته اند. هرجند در يُوهش بيتون و همكاران، (Y) (Y) مشاهده شد تأثير دختران و پسران بر والدين متفاوت است. با اين وجود در يزوهش حاضر؛ شايد عدم معنىدارى عامل جنسيت به دليل نوع كمتوانى و شدت آسيبهاى ناشى از آن باشد. جرا كه آسيب جسمى حركتى باعث وابستگى بيشتر اين فرزندان و اجبار والدين به ارائه خدمات مراقبتى و بهداشتى بيشتر جه به فرزندان

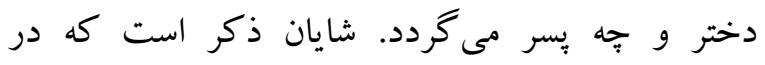
يثوهش حاضر در حين مراجعه حضورى در منازل آزمودنىها و ارتباط مستقيم با والدين؛ بر اساس

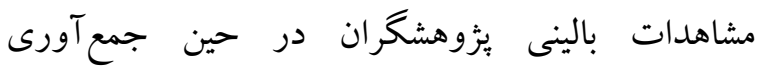

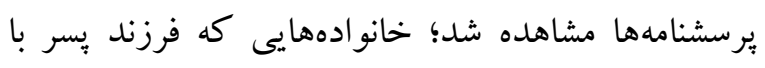
آسيب جسمى حركتى داشتند؛ نسبت به خانوادههايى كه فرزند دختر با آسيب جسمى حر كتى داشتند، فشار روانى، اجتماعى و عاطفى بيشترى را گزارش مى كردند. آنها

\footnotetext{
- Duvdevany\&Abboude

${ }^{2}$ - Pinquart
} 


\section{References}

Alriksson-Schmidt AI, Wallander J, Biasini F. (2007). Quality of life and resilience in adolescents with a mobility disability. Joumal of pediatric psychology, 32(3), 370-379.

Arman S, FirouzkuhiMoghaddam M. (2002). The Impact of Psychological Interventions on the Problems of Siblings. Tayeb East Joumal, 6(4), 267-271. (In Persian)

Bararil B, Ghaffari M. (2015). Mental Health of Physically Disabled Persons Compare to the Normal People: Investigation Based On the Psychopathology and Positive Psychology Approaches. Middle Eastem Journal of Disability Studies, 5(11), 281-288. (In Persian)

Bastaminia A, Hashemi FB, Alizadeh M, Dastoorpoor M. (2016). Resilience and Mental Health: A Study among Students at the State University of Yasuj City. British Joumal of Education, Society \& Behavioural Science, 18(2), 1-9.

Besharat MA, AbbaspourDoplani T. (2011). The relationship between metacognitive strategies and creativity with resilience in students. M.Sc., Islamic Azad University, Ahvaz Branch. New Findings in Psychology (Social Psychology) 5(11), 111-124. (In Persian)

Betancourt TS, Meyers- Ohki SE, Charrow A, Hansen N. (2013). Annual research review: Mental health and resilience in HIV/AIDS- affected children-a review of the literature and recommendations for future research. Joumal of Child Psychology and Psychiatry, 54(4), 423-444.

Bishop M, Greeff AP. (2015). Resilience in families in which a member has been diagnosed with schizophrenia. Journal of psychiatric and mental health nursing, 22(7), 463-471.

Carle AC, Chassin L. (2004). Resilience in a community sample of children of alcoholics: Its prevalence and relation to internalizing symptomatology and positive affect. Joumal of Applied Developmental Psychology, 25(5), 577-595.

Choi EK, Yoo IY. (2015). Resilience in families of children with Down syndrome in Korea.
بر اساس مطالعات اكثر والدينى كه يكى از فرزندان آنها دجار بيمارى خاص يا كمتوانى هستند؛ نياز به يكك باور قوى در مورد فرزند خود و كمتوانى و آينده او دارند تا يكك جشمانداز خوشبينانه و ديدكاه قوى در مورد كم توانى او به دست بياورند و بتوانند راحت تر با كمتوانى فرزند خود كنار بيايند، آن را بيذيرند و آينده بهترى براى فرزند خود تصور كنند و در مواجهه با اين بخش از زندكى خود كه نمىتواند تغيير دهند به ميزان بالاترى از تابآورى و ساز كارى برسند (موهن و كولكارنى،

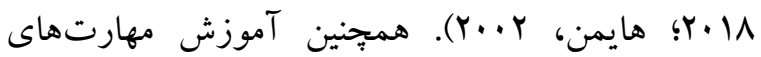
مقابلهاى و شيوه اسناد درونى مىتواند تابآورى والدين افراد با آسيب ذهنى را افزايش دهد (راجان، سريكريشنا و

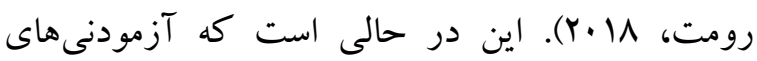
يثزوهش حاضر از هيج يكك از اين خدمات و مداخله ها برخوردار نبودند؛ بنابراين با توجه به پايين بودن ميزان تاب آورى و سلامت روانى در گرووه مورد مطالعه بيشنهاد مى گردد به آموزش مهارتهاى تابآورى و سلامت روان به والدين افراد با آسيب جسمى حركتى جهت كنار آمدن راحت تر با محدوديت فرزند خود و برخورد بهتر با شرايطى كه در آن قرار دارند؛ برداخته شود.

\section{سياسگزارى} اين مقاله حاصل پياياننامه كارشناسى ارشد رشت رشته روانشناسى و آموزش كودكان استثنايى دانشگاه شيرازمى باشد. بدينوسيله از همه همكاران محترم در سازمانهاى آموزشويرورش و بهزيستى شيراز و والدين محترمى كه در اجراى اين بثزوهش بنده را يارى نمودند،

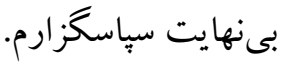


International joumal of nursing practice, 21(5), 532-541.

Conner KM, Davidson JRT. (2003). Development of a new resilience scale: The Conner-Davidson Resilience Scale (CD-RISC). Depression and Anxiety, 18, 76-82.

Donnellan WJ, Bennett KM, Soulsby LK. (2016). Family close but friends closer: exploring social support and resilience in older spousal dementia carers. Aging \& Mental Health, 21(11), 1-7.

Duvdevany I, Abboud S. (2005). Stress, social support and well- being of Arab mothers of children with intellectual disability who are served by welfare services in northem Israel. Joumal of Intellectual Disability Research, 47(45), 264 272.

Dyson LL. (1991). Families of young children with handicaps: Parental stress and family functioning. American Journal on Mental Retardation, 95(6), 623-629.

Frajo-Apor B, Pardeller S, Kemmler G, Hofer A. (2015). Emotional Intelligence and resilience in mental health professionals caring for patients with serious mental illness. Psychology, health \& medicine, 21(6), 75561.

Goldberg DP, Hillier VF. (1979). A scaled version of the General Health Questionnaire. Psychological medicine, 9(01), 139-145.

Greeff AP, Vansteenwegen A, Gillard J. (2012). Resilience in families living with a child with a physical disability. Rehabilitation nursing. The official joumal of the Association of Rehabilitation Nurses, 37(3), 97-104.

Hagh Ranjbar F, Kakavand AS, Borjali A, Bermas H. (2012). Resilience and quality of life of mothers with mentally retarded children. 1(1), 179-189. (In Persian)

Heiman T. (2002). Parents of children with disabilities: Resilience, coping, and future expectations. Journal of developmental and physical disabilities, 14(2), 159-171.

Jones L, Gold E, Totsika V, Hastings RP, Jones, M, Griffiths A, silverton S. (2018). A mindfulness parent well-being course: evaluation of outcomes for parents of children with autism and related disabilities recruited through special schools. European Joumal of Special Needs Education. 33(1), 16-30.

Jowkar B. (2008). The mediating role of resilience in the relationship between general and emotional intelligence and life satisfaction. Contemporary psychology, 2(2), 3-12. (In Persian)

Kabasakal Z, Girli A, Totan T, Aysan F. (2012). Psychiatric symptoms as predictors of life satisfaction in parents with handicapped children. Journal of Theory and Practice in Education, 8(2), 1-17.

Khodabakhshi Koolaee A, Derakhshandeh M. (2015). Effectiveness of hope-oriented group therapy on life meaning and resilience in mothers with physical-motor disabled children. Iranian joumal of pediatric nursing.1(3),15-25. (In Persian)

Lal S, Ungar M, Malla A, Leggo C, Suto M. (2017). Impact of Mental Health Services on Resilience in Youth with First Episode Psychosis: A Qualitative Study. Administration and Policy in Mental Health and Mental Health Services Research, 41(1), 91-102.

Lightfoot E, Hill K, LaLiberte T. (2011). Prevalence of children with disabilities in the child welfare system and out of home placement: An examination of administrative records. Children and Youth Services Review, 33(11), 2069-2075.

Lueger Schuster B, Weindl D, Kantor V, Knefel M, Glück T, Moy Y, Jagsch R. (2014). Resilience and mental health in adult survivors of child abuse associated with the institution of the Austrian Catholic Church. Joumal of traumatic stress, 27(5), 568-575.

Mahdavi A, Ahmadi M, NadrMohamadi M, Adham D. (2011). The relationship between mental health and selfesteem in students of medical sciences. Journal of Society for development in new net environment in B\&H. 7(1), 151157.

Malekshahi F, Falahi Sh. (2016). Psychosocial 
Problems of Parents of Mentally Disabled Children Covered by Khorram Abad Wellbeing Center 2013. Yafte, Joumal of Lorestan University of Medical Sciences, 18 (3), 42-51. (In Persian)

McConnell D, Savage A, Breitkreuz R. (2014). Resilience in families raising children with disabilities and behavior problems. Research in developmental disabilities, 35(4), 833-848.

Meikaeilei N, Ganji M, TalebiJoybari M. (2012). A comparison of resiliency, marital satisfaction and mental health in parents of children with leaming disabilities and normal children. Journal of Leaming Disabilities, 2(1), 120-137. (In Persian)

Mohan R, Kulkarni M. (2018) Resilience in Parents of Children with Intellectual Disabilities. Psychology and Developing Societies, 30(1), 19-43.

Najafi M, Bigdeli E, Dehshiri Gh, RahimianBogar A, Tabatabai M. (2012). The Role of Life Skills in Predicting Students' Mental Health. Counseling and Psychotherapy Culture, 11 (3), 101-116.(In Persian)

Patton KA, Ware R, McPherson L, Emerson E, Lennox N. (2018). Parent Related Stress of Male and Female Carers of Adolescents with Intellectual Disabilities and Carers of Children within the General Population: A Cross Sectional Comparison. Joumal of Applied Research in Intellectual Disabilities, 31(1), 5161.

Peer JW, Hillman SB. (2014). Stress and resilience for parents of children with intellectual and developmental disabilities: a review of key factors and recommendations for practitioners. Journal of Policy and Practice in Intellectual Disabilities, 11(2), 92-98.

Pinquart M. (2018). Depressive Symptoms in Parents of Children with Chronic Health Conditions: A Meta-Analysis. Journal of Pediatric Psychology, 36(4), 375-84.

Prince-Embury S. (2007). The resiliency scales for children and adolescents: profiles of strengths. San Antonio, TX: Harcourt Assessments.

Rajabi S, Assareh M, Keshvari F. (2014). Evaluation of
Students' Mental Health and Relation to Resilience and Copping Styles. International Joumal of School Health, 1(1).

Rajan A, Srikrishna G, Romate J. (2018). Resilience and Locus of Control of Parents Having a Child with Intellectual Disability. Journal of Developmental and Physical Disabilities, 30(3), 297-306.

Resch JA., Mireles G, Benz MR, Grenwelge C, Peterson R, Zhang D. (2010). Giving parents a voice: A qualitative study of the challenges experienced by parents of children with disabilities. Rehabilitation Psychology, 55(2), 139-150.

Roder I, Boekaerts M. (1999). Stress, coping, and adjustment in children with a chronic disease: a review of the literature. Disability and rehabilitation, 21(7), 311-337.

Schaible B, Colquitt G, Caciul MC, Carnes A, Li L, Moreau N. (2018). Comparing impact on the family and insurance coverage in children with cerebral palsy and children with another special healthcare need. Child Care Health Dev, 44(3), 370-377.

Shpiegel S. (2016). Resilience A mong Older Adolescents in Foster Care: The Impact of Risk and Protective Factors. International Joumal of Mental Health and Addiction, 14(1), 6-22.

Siriwardhana C, Ali SS, Roberts B, \& Stewart R. (2014). A systematic review of resilience and mental health outcomes of conflict-driven adult forced migrants. Conflict and health, 8(1), 8-13.

Smith TEC, Polovy EE, Davty T, Patten JR, Davdy KE. (2012). Psychology and education of students with special needs. Translated by Hemmati Alamdarloo et al. (2016); Tehran: Arasbaran Publications. (In Persian)

Taghavi SMR. (2000). Validation and Operation of a Public Health Program (G.H.Q). Joumal of Psychology, 2, 398-381. (In Persian)

Woodgate RL. (1998). Adolescent's perspective of chronic illness: IT is hard. Joumal of pediatric Nursing. 13(4): 210-223.

World Health Organization (2014). Mental health: a 
state of well - being. http:/ /www.who.int/features/factfiles/mental_health len/

World Health Organization (2018). Disability and health: http://www.who.int/mediacentre/factsheets/fs3 52/en/ 